DOI: https://doi.org/10.32839/2304-5809/2021-11-99-67

УДК $343.13(477)$

Крицька І.О., Верещака Я.В.

Національний юридичний університет імені Ярослава Мудрого

\title{
ДО ПИТАННЯ ПРО СИСТЕМУ ГАРАНТІЙ ПРОВЕДЕННЯ ДОПИТУ ПІД ЧАС ПАНДЕМІЇ COVID-19
}

Анотація. Стаття присвячена визначенню гарантій проведення дистанційного допиту під час карантинних обмежень в Україні, забезпечення яких супроводжуеться значною кількістю невирішених питань, які в умовах поширення коронавірусної інфекції COVID-19 набули ще більшої гостроти. Авторами проведено аналіз Закону України № 558 IX, яким встановлено особливості кримінального провадження у зв’язку з COVID-19, та визначено проблемні питання його застосування при проведені дистанційного допиту. Досліджено окремі проблеми, пов'язані з можливістю реалізації під час відеоконференції допитуваними особами своїх прав, якими вони наділені у разі проведення «звичайного допиту». На основі проведеного дослідження авторами виокремлено переваги та недоліки використання режиму відеоконференції у кримінальному процесі, зокрема з метою проведення допиту, виокремлено напрямки вдосконалення вітчизняного кримінального процесуального законодавства з цього аспекту. Також автори звернулися до досвіду зарубіжних країн (Республіки Молдови, Республіки Казахстан), у яких цифровому перетворенню судів приділялося достатньо уваги упродовж останніх років, та проаналізували заходи, які в умовах пандемії COVID-19 сприяли забезпеченню належного захисту прав, свобод та інтересів особи.

Ключові слова: допит, досудове розслідування, дистанційний допит під час пандемії COVID-19, система гарантій проведення допиту в режимі відеоконференщіі, забезпечення права на переклад, Єдина судова інформаційно-телекомунікаційна система.

Krytska Iryna, Vereshchaka Yarina Yaroslav Mudryi National Law University

\section{TO THE QUESTION OF THE SYSTEM OF GUARANTEES OF INTERROGATION DURING THE COVID-19 PANDEMIC}

Summary. The article is devoted to the definition of guarantees of remote interrogation during quarantine restrictions in Ukraine, the provision of which is accompanied by a significant number of unresolved issues, which in the context of the spread of coronavirus infection COVID-19 have become even more acute. The authors analyzed the Law of Ukraine № 558 IX, which established the features of criminal proceedings in connection with COVID-19, and identified problematic issues of its application during remote interrogation. Some problems related to the possibility of exercising their rights during the videoconference by the interrogated persons, which they are endowed with in the case of "ordinary interrogation", have been studied. The authors highlight the advantages and disadvantages of using videoconferencing in criminal proceedings, in particular for the purpose of interrogation. Finally, the authors turn to a comparative analysis of certain provisions of foreign law in terms of possible regulatory borrowing. In particular, the experience of foreign countries (Republic of Moldova, Republic of Kazakhstan), in which the digital transformation of courts has been given sufficient attention in recent years, was studied, and measures were taken to ensure proper protection of individual rights, freedoms and interests in the COVID-19 pandemic. Based on the study, the authors concluded that the use of remote interrogation helps to improve the quality and reasonable speed of justice, ensuring its accessibility and exercising the right to judicial protection. However, at the present stage of development of Ukrainian statehood, the use of videoconferencing in criminal proceedings, in particular for interrogation, which is extremely important in today's conditions, is associated with a number of shortcomings that prevent proper effective pre-trial investigation and trial. Therefore, these unresolved issues need to be addressed immediately in order to ensure the administration of justice and the realization of a person's right of access to a court, especially in the context of the spread of COVID-19 coronavirus infection, the directions of improvement of the domestic criminal procedural legislation on this aspect are singled out.

Keywords: interrogation, pre-trial investigation, remote interrogation during the COVID-19 pandemic, system of guarantees of interrogation by videoconference, ensuring the right to translation, Unified Judicial Information and Telecommunication System.

Постановка проблеми. Для сучасного кримінального процесу пандемія COVID-19 стала серйозним викликом, який виявив ряд проблем, які раніше з такою гостротою ще не поставали. Перед правоохоронними та судовими системами держав постали нові завдання, пов'язані із необхідністю так організувати кримінальну процесуальну діяльність, щоб забезпечення ефективного досудового розслідування та судового розгляду, дотримання традиційних базових принципів не суперечило реалізації громадянами права на життя, здоров'я та безпеку.
Очевидно, що всі механізми, так чи інакше, дозволяють віднайти баланс між процесуальними правами учасників кримінального судочинства, включаючи право на справедливий судовий розгляд, і правами, які, зокрема з метою протиепідемічного захисту, вимагають більш активного використання сучасних інформаційних технологій. До того ж, використання інструментарію цифрового суспільства в рамках кримінального процесу буде значимим і в постпандемічний період, оскільки дозволить забезпечити доступ до правосуддя тих осіб, які є маломобільними через 
вік чи стан здоров'я, або територіально перебувають далеко від певного органу досудового розслідування та суду. Цими обставинами і пояснюеться високий інтерес як правозастосовників, так і науковців до технологій, що дають змогу забезпечити дистанційний допит у кримінальному провадженні.

Аналіз останніх досліджень i публікацій. 3-поміж наукових робіт, присвячених питанню реалізації дистанційного допиту, зокрема i в умовах COVID-19, заслуговують на увагу наукові праці вітчизняних і зарубіжних учених, зокрема таких як С. Бойко, О. Капліна, В. Князев, М. Погорецький, Т. Пасюк, О. Старенький, А. Туманянц, П. Цимбал, С. Шаренко, Д. Шингарьов, Н. Шульга та інших.

Виділення невирішених раніше частин загальної проблеми. Незважаючи на вагомі наукові праці та поточні дослідження, наразі невирішеними залишаються окремі аспекти реалізації дистанційного допиту, зокрема і в контексті співставлення з іншими процесуальними галузями права, що значно ускладнюе належний захист прав, свобод та інтересів особи, особливо в сучасних умовах під час поширення коронавірусної інфекції COVID-19 та актуалізації потреби пошуку нових способів залучення особи до участі в процесуальних діях.

Метою статті $є$ визначення системи гарантій проведення дистанційного допиту під час карантинних обмежень в Україні, з'ясування їх змісту та аналіз досвіду іноземних держав з цього аспекту.

Виклад основного матеріалу. Світова пандемія COVID-19 внесла суттеві корективи у звичайне суспільне життя, оскільки людство змушене пристосовуватись до нових реалій сьогодення. Вочевидь, зміни не могли не торкнутися і судової гілки влади, зокрема виникнення ситуацій, коли учасники кримінального провадження через введені карантинні обмеження, підвищений ризик захворюванню тощо не можуть постати перед стороною обвинувачення або судом. Наведені фактори, буз сумніву, актуалізували та значно підвищили необхідність проведення дистанційного допиту з метою забезпечення доступу до правосуддя.

Звичайно, що законодавець відреагував на таку потребу i, враховуючи сучасну ситуацію, 13 квітня 2020 p. Верховною Радою України було прийнято Закон України № 558 IX, яким встановлено особливості кримінального провадження у зв'язку з COVID-19. Зокрема передбачено, що розгляд питань, віднесених до повноважень слідчого судді, суду (крім розгляду клопотання про обрання запобіжного заходу у вигляді тримання під вартою) за його рішенням, прийнятим із власної ініціативи або за клопотанням сторони кримінального провадження, може бути проведено в режимі відеоконференції, про що повідомляються сторони кримінального провадження в порядку, визначеному ст. 135 КПК України [1]. Водночас, чи достатньо наведених змін для того щоб повністю вирішити всі проблемні питання, що постають в таких обставинах перед правозастосовниками?

Зокрема, у контексті зазначеного, слід погодитися 3 думкою М. А. Погорецького та О. С. Старенького стосовно вибіркового підходу законодавця до визначення кола суб'єктів, які мають бути повідомлені про проведення процесуальних дій у режимі відеоконференції - зокрема, учені слушно наголошують на тому, що окрім сторін інші учасники кримінального провадження (потерпілий, свідок, експерт, перекладач тощо) також можуть брати участь у проведенні процесуальних дій у режимі відеоконференції, однак відповідний обов'язок слідчого судді чи суду на них чомусь не поширюеться [2]. Тим більше, що розгляд значної частини питань, віднесених до компетенщії, зокрема, слідчого судді, може здійснюватися, коли сторона захисту взагалі відсутня. 3 огляду на це, наведене нормативне положення мае бути уточнено.

На продовження цього доцільно додати, що, на відміну від інших процесів, у кримінальному його учасникам так і не було надано можливості брати дистанщійну участь в режимі відеоконференції 3 використанням власних технічних засобів (смартфонів, ноутбуків тощо), оскільки незмінним залишилося положення щодо участі в засіданні з використанням засобів відеоконференції лише з приміщення іншого суду або СІЗО. На цій проблемі акцентовано увагу в окремих публікаціях [3].

Крім того, слід зазначити, що ні положеннями ст.ст. 232, 336 КПК України [4], ні зазначеним вище Законом не врегульовано питання щодо строку, за який сторони чи інші учасники кримінального провадження зобов'язані подати клопотання про проведення процесуальних дій, зокрема дистанщійного допиту, у режимі відеоконференції в рамках кримінального провадження, розгляд якого вже призначений у загальному порядку на певну дату. Наведене питання особливо актуальне в умовах поширення хвороби коронавірусу (COVID-19) та неможливості забезпечити присутність свідків, потерпілих, експертів, підозрюваних чи обвинувачених на призначену дату судового засідання в деяких справах [5, с. 410]. У світлі цього слід також звернути увагу на те, що, виходячи з аналізу положень ст. 232 КПК, використання дистанційного способу під час допиту слідчим, прокурором може бути ініційовано лише цими суб'єктами тобто для допитуваних осіб не регламентовано алгоритму дій, коли вони самі через наявність відповідних підстав до цього бажають бути допитані саме за допомогою відеоконференцзв'язку. На наш погляд, вказаний аспект має бути врегульований або у ст. 232 КПК, або у відповідних статтях (наприклад, ст.ст. 42, 56, 66 тощо) глави 3 КПК України як одне із прав таких учасників.

$\mathrm{y}$ ключі піднятого питання відмітимо, що деякі автори заперечують можливість допиту підозрюваних i обвинувачених у режимі відеоконференцзв'язку, мотивуючи це тим, що процесуальний статус обвинуваченого передбачае певне обмеження його прав, зокрема обов'язок явки до органів розслідування та суду, застосування до нього заходів кримінально-процесуального примусу. Відповідно, його перебування поза місцем провадження досудового розслідування виключено, та підстави для застосування відеоконференцзв'язку відсутні [6, с. 23]. Однак ми вважаемо, що в умовах пандемії нагально необхідне використання в тому числі можливості дистанційного допиту підозрюваних і обвинувачених, коли явка, так само як 
і будь-які їх пересування, можуть нести ризик не лише для них самих, але й для оточуючих, або ж така явка може бути неможливою через незалежні від них фрактори.

Зауважимо також, що у спеціальній науковій літературі з цього питання звертається увага на окремі проблеми, пов'язані 3 можливістю реалізації під час відеоконференції допитуваними особами своїх прав, якими вони наділені у разі проведення «звичайного допиту». Йдеться, зокрема, про: (а) особливості реалізації права на користування нотатками при даванні показань [7, с. 157]; (б) забезпечення права на ефрективну професійну правничу допомогу [7, с. 157]; (в) належне представництво окремих учасників [9, с. 128]; забезпечення права на переклад [7, с. 158]; реалізацію окремими учасниками свого права на відмову від давання показань [10, с. 217] тощо.

Задля уникнення зайвого дублювання наведених наукових позицій, детально висвітлених у відповідній літературі, зупинимося лише на окремих аспектах. Зокрема:

- по-перше, позитивним прикладом для запозичення 3 погляду компаративного аналізу видаеться положення, що міститься у ч. 5 ст. 210 КПК Республіки Казахстан, а саме якщо показання пов'язані 3 цифровими даними або іншими відомостями, які важко утримати в пам'яті, допитуваний має право користуватися документами і записами в письмовій чи будь-якій іншій формі, які за клопотанням або за згодою допитуваної особи, можуть бути долучені до протоколу. При цьму в коментарі до цієї статті вказано, що для реалізації такого права не вимагається дозвіл особи, яка проводить допит. За клопотанням допитуваної особи документи і записи особа, яка проводить допит, має право додати до протоколу допиту в разі, якщо вони мають значення у справі, а для залучення їх до протоколу з ініціативи особи, яка проводить допит, необхідна згода допитуваної особи. У випадку, якщо така згода не отримана, особа, яка проводить допит, має право винести постанову про їх виїмку і приеднання до справи [8];

- по-друге, задля надання можливості на конфіденційне спілкування між адвокатом та його клієнтом (підозрюваним, потерпілим, свідком тощо) може бути розглянуто два варіанти: або ці суб'єкти мають перебувати в одному місці, так би мовити «по один бік» відеоконференції, або мають бути створені технічні умови, які забезпечать їх спілкування за відсутності інших суб'єктів (наприклад, через використання такої технічної функції в Zoom, як «сесійні зали» («breakout rooms»), але тільки з урахуванням гарантій обмеження аудіо-, відеофіксації, що передбачені, зокрема, у ст. 46 КПК України);

- по-трете, наведені вище пропозищії можуть бути застосовані й в контексті проблеми місцеперебування законних представників (оскільки в літературі акцентовано на доцільності їх знаходження виключно поруч із неповнолітніми, недієздатними чи обмежено дієздатними особами, які беруть участь у проведенні процесуальних дій під час кримінального провадження) [9, с. 128], а також як варіант вирішення питання щодо ступеню володіння перекладачем, який залучається, мовою, на яку має здійснюватися переклад [7, с. 158];
- по-четверте, суттевим ускладненням в реалізації загальних вимог щодо проведення допиту в режимі відеоконференції $є$ відсутність чіткого врегулювання питання, в який спосіб особа, яка допитуеться дистанційно, повинна підписати протокол, засвідчити роз'яснення їй прав, обов'язків та відповідальності за відмову давати покази і за дачу завідомо неправдивих показань. Видається, що врегулювання можливе шляхом застосування електронного протоколу допиту, який можливо підписати, реалізуючи на практиці процедуру електронного підпису людини (цифрового підпису) та електронної форми розписки.

Досліджуючи питання використання режиму відеоконференції у кримінальному процесі, зокрема 3 метою проведення допиту, варто визначити наступні його переваги та недоліки (див. табл. 1).

Отже, на сучасному етапі розвитку української державності питання використання режиму відеоконференції у кримінальному процесі, зокрема 3 метою проведення допиту, яке має надзвичайно важливе значення в умовах сьогодення, водночас пов'язане із значною кількістю недоліків, що унеможливлюють належне забезпечення ефективного досудового розслідування та судового розгляду. Утім, вищезазначені недоліки можливо усунути, зокрема, шляхом внесення відповідних нормативних коректив, а також використання належного програмного забезпечення та технічного устаткування тощо.

3 метою забезпечення належного захисту прав, свобод та інтересів особи пропонуємо визначити систему гарантій проведення допиту в режимі відеоконференщії, зокрема, і в умовах пандемії:

(1) гарантії, пов'язані із забезпеченням конституційних прав особи: а) встановлення переліку підстав проведення допиту в режимі ст. 232 КПК (зокрема, й для забезпечення права на захист життя і здоров'я); б) забезпечення права на профресійну правничу допомогу; в) захист інформації, що передається каналами зв'язку під час відеоконореренції, та недопустимість незаконного втручання в неї;

(2) гарантії пов'язані із здійсненням ефективного досудового розслідування: а) використання належного програмного і технічного забезпечення; б) залучення спеціаліста до проведення дистанщійного допиту; в) регламентація можливості допиту особи не тільки у спеціально відведених місцях та 3 використанням стаціонарного обладнання, а й з будь-якого місця, де особа перебуває, та із застосуванням їі власних технічних засобів (що наразі вже регламентовано для інших видів процесу).

У світлі вищезазначеної системи гарантій підкреслимо, що частина 3 них вже втілена в КПК, водночас інші, на наш погляд, мають бути регламентовані якнайшвидше.

Наостанок звернемося до компаративного аналізу окремих положень зарубіжного законодавства 3 погляду можливого нормативного запозичення. Відмітимо, що під час карантинних обмежень у більш виграшному становищі виявилися судові системи тих держав, у яких саме цифровому перетворенню судів приділялося достатньо уваги упродовж останніх років.

Зокрема, відповідно до ст. 110 КПК Республіки Молдова, якщо є вагомі підстави вважати, що життя, недоторканність або свобода свідка, 
Таблиця 1

\begin{tabular}{|l|}
\hline \multicolumn{1}{|c|}{ Переваги } \\
\hline $\begin{array}{l}\text { Можливість відмежувати особу, до якої застосовується } \\
\text { відеоконференція, від небезпечного для неї учасника } \\
\text { кримінального процесу або ж взагалі залишити таку } \\
\text { особу невідомою }\end{array}$ \\
la
\end{tabular}

Зменшення фінансових витрат, зокрема на прибуття осіб до місця проведення допиту, а також інші процесуальні витрати, пов'язані з цим

Можливість залишити особу, що допитуеться дистанційно, невідомою для учасника кримінального провадження, який є для неї небезпечним

Уможливлення допиту в тих випадках, коли фрізична присутність особи через хворобу,

пандемію, карантинні обмеження, інші обставини $е$ неможливою або надмірно ускладненою (вказане 3 одного боку має важливе значення для забезпечення ефрективного, зокрема оперативного, кримінального провадження, а з іншого сприяе зменшенню ризику поширення інфекційних хвороб)

Неможливість або неврегульованість порядку подання на розгляд слідчого, прокурора, слідчого судді, суду письмових клопотань, доказів та інших процесуальних документів, які знаходяться в особи, стосовно якої проводиться допит

Проблеми реалізації права на конфіденційне спілкування між адвокатом та його кліентом під час допиту

Ускладнення, пов'язані з перевіркою компетенції перекладача у разі його залучення в кримінальному провадженні

Відсутність чіткого врегулювання питання місцеперебування окремих учасників у випадку застосування режиму відео конференції

Не передбачення в законодавстві алгоритму підписання особою, яка допитуеться дистанційно, протоколу, надання нею письмового підтвердження роз'яснення їй прав, обов'язків та відповідальності за відмову давати покази і за надання завідомо неправдивих показань

Недостатній для нормального спілкування рівень технічного зв'язку, у тому числі періодичне зникнення звуку і зображення під час відеоконференції, перешкоджання шумів та відлуння для повного розуміння висловлених учасниками процесу фраз

Не надання учасникам можливості брати участь в дистанційному проведенні процесуальних дій з використанням власних технічних засобів

Джерело: розроблено авторами на основі власних досліджень

його близького родича знаходяться в небезпеці у зв'язку з наданими їм показаннями у справі про тяжкий, особливо тяжкий або надзвичайно тяжкий злочин, і якщо є відповідні технічні засоби, суддя може допустити, щоб цей свідок допитувався не за місцем розташування органу кримінального переслідування або в залі судового засідання, а за допомогою відповідних технічних засобів. При цьому, згідно з ч. 5 цієї статті, свідок може бути допитаний за допомогою закритої телеконфреренції з такою зміною зовнішності і голосу, щоб його неможливо було впізнати. Обвинуваченому, підсудному, їх захисникам, а також потерпілому забезпечуеться можливість задавати питання свідкові, допитуваному. Показання свідка, допитуваного відповідно до положень ціеї статті, записуються за допомогою технічних засобів відеозапису і повністю вносяться в протокол [11].

Відзначимо, що в умовах пандемії Верховний Суд Республіки Казахстан закликав місцеві суди забезпечити неухильне дотримання Постанови для виключення ризиків зараження COVID-19 у будівлях судів і створення безпечних умов для відвідувачів, суддів і працівників. З огляду на напрацьований позитивний досвід, суди Республіки Казахстан продовжують фрунціонувати в режимі онлайн, а проведення судових засідань у кримінальних справах 3 фрізичною присутністю сторін у будівлі суду допускається тільки у виняткових випадках. Скарги, клопотання й інші документи рекомендуеться направляти за допомогою «Судового кабінету», а матеріали, що містяться на паперових носіях, сканувати і відправляти в електронному форматі [12]. Контекстно зазначимо, що користувачі «Судового кабінету» - єдиного електронного вікна до доступу до всіх судових послуг можуть з будь-якого гаджета, не виходячи з дому, направити в суд понад 90 видів електронних звернень. Такий сервіс значно економить кошти 3 документообігу, але, перш за все, він дає можливість стороні брати участь в засіданні без виїзду в суд, незалежно від місця свого знаходження. Для цього йому достатньо звернутися із заявою у «Судовому кабінеті», який йому повідомить про час виходу на відеоконференцзв'язок з судом [13]. Водночас, у зв'язку з цим доцільно відмітити позитивні зрушення, що нарешті відбулися в кримінальному процесі України - зокрема, на підставі оголошення Вищої ради правосуддя [14], відбувся початок фонкціонування Єдиної судової інформаційно-телекомунікаційної системи, зокрема, використання офріщійних електронних адрес та процедури реєстращії, автентифікації та доступу осіб до функціонуючих підсистем (модулів) СCITC (електронний кабінет), що більш детально регламентовано Положенням про порядок фрункціонування окремих підсистем Єдиної судової інфрормаційнотелекомунікаційної системи [15].

Висновки i пропозиції. Застосування дистанщійного допиту сприяє підвищенню якості й розумної швидкості правосуддя, забезпечення його доступності та реалізації права на судовий захист.

Однак здійснення дистанційного допиту в Україні супроводжується значною кількістю не- 
вирішених питань, які в умовах поширення коронавірусної інфрекції COVID-19 набули ще більшої гостроти. Способи вирішення проблем реалізаціі дистанційного допиту повинні мати комплексний характер i вимагають перегляду нормативної основи та інформатизації діяльності органів досудового розслідування та судів. Нормативне вдосконалення правил проведення дистанційного допиту потребує певного універсального підходу, який, з одного боку, дозволить визначити гарантії прав учасників процесу та захистить їх від необIрунтовано широких дискреційних повноважень правозастосовного органу, а, з іншого, - дозволить застосовувати норми більш гнучко та адаптувати загальні підходи до дистанщійного допиту до всього різноманіття ситуацій допиту. Для досягнення істотного результату Україні також необхідно запозичувати іноземний досвід держав, які вже давно працюють над впровадженням інституту дистанщійного допиту та мають позитивні здобутки.

\section{Список літератури:}

1. Про внесення зміни до пункту 20-5 розділу XI "Перехідні положення" Кримінального процесуального кодексу України щодо особливостей судового контролю за дотриманням прав, свобод та інтересів осіб у кримінальному провадженні та розгляду окремих питань під час судового провадження на період дії карантину, встановленого Кабінетом Міністрів України з метою запобігання поширенню коронавірусної хвороби (COVID-19) : Закон України від 13 квітня 2020 р. № 558-IX. URL: https://zakon.rada.gov.ua/laws/show/558IX\#Text (дата звернення: 23.11.2021).

2. Встановлюемо дистанцію! Закон і Бізнес : веб-сайт. URL: https://zib.com.ua/ua/142090-distanciyne_kriminalne_ provadzhennya_v_umovah_p-oshirennya_ko.html (дата звернення: 23.11.2021).

3. Бойко С. Кримінальна практика «під соусом» пандемії. Юридична газета. 2020. № 22(728). URL: https://yur-gazeta.com/publications/practi-ce/kriminalne-pravo-ta-proces/kriminalna-praktika-pid-sousompandemiyi.html (дата звернення: 23.11.2021).

4. Кримінальний процесуальний кодекс України : Кодекс України від 13 квітня 2012 p. № 4651-VI. URL: https://zakon.rada.gov.ua/laws/show/4651-17\#Text (дата звернення: 07.11.2021).

5. Пасюк Т. В., Цимбал П. В. Проблемні питання застосування режиму відеоконференції у кримінальному процесі під час пандемії. Юридичний науковий електронний журнал. 2020. № 8. С. 408-411.

6. Овчинникова О. В. Перспективы использования видеоконференц-связи в электронном судопроизводстве. Правопорядок: история, теория, практика. 2018. № 4(19). С. 21-25.

7. Капліна О. В., Туманянщ А. Р., Шаренко С. Л. Судочинство у кримінальному провадженні під час пандемії COVID-19: міжнародний досвід та вітчизняна практика. Порівняльно-аналітичне право. 2020. № 3. C. $141-167$.

8. Комментарий к главе 26 УПК Республики Казахстан. URL: https://online.zakon.kz/Document/?doc_id= 33547929\#pos=5;-108 (дата звернення: 07.11.2021).

9. Князев В. В. Дистанційне кримінальне провадження: проблемні питання та перспективи. Пріоритетні напряли модернізацї системи права : матеріали II Науково-практичної конференції, м. Запоріжжя, 15-16 травня 2020 р. Херсон : Молодий вчений, 2020. С. 126-131.

10. Шингарьов Д. О. Окремі питання забезпечення прав та законних інтересів осіб при проведенні допиту у режимі відеоконференції під час досудового розслідування. Проблели законності. 2016. Вип. 135. С. $212-224$.

11. Уголовно-процессуальный кодекс Республики Молдова от 14.03.2003 № 122-XV. URL: http://continent-online.com/ Document/?doc_id=3039-7729\#pos-=6;-143 (дата звернення: 09.11.2021).

12. Как работают суды после снятия режима ЧП? Верховный суд Республики Казахстан : веб-сайт. URL: https://sud.gov.kz/rus/news/kak-rabotayut-sudy-posle-snyatiya-rezhima-chp (дата звернення: 14.11.2021).

13. Казахстанцы могут обратится в суд с любого гаджета. Верховный суд Республики Казахстан : веб-сайт. URL: https://sud.gov.kz/rus/news/kazah-stancy-mogut-obratitsya-v-sud-s-lyubogo-gadzheta (дата звернення: 14.11.2021).

14. Про початок фрункціонування відповідних підсистем (модулів) Єдиної судової інформаційно-телекомунікаційної системи (ССITC) : оголошення Вищої ради правосуддя від 04.09.2021 p. URL: https://zakon.rada.gov.ua /rada/show/n0001910-21\#n5 (дата звернення: 18.11.2021).

15. Положення про порядок функціонування окремих підсистем Єдиної судової інформаційно-телекомунікаційної системи : рішення Вищої ради правосуддя від 17.08.2021 № 1845/0/15-21. URL: https://zakon.rada.gov.ua/ rada/show/v1845910-21\#n22 (дата звернення: 18.11.2021).

\section{References:}

1. On making amendments to paragraph 20-5 of Section XI «Transitional Provisions» of the Criminal Procedure Code of Ukraine on peculiarities of judicial control over the observance of rights, Freedoms and Interests of Persons in Criminal Proceedings and Examination of Certain Matters during Court Proceedings for the Quarantine Period, established by the Cabinet of Ministers of Ukraine to Prevent the Spread of Coronavirus Disease (COVID-19): Law of Ukraine of June 13, 2020. № 558-IX. Available at: https://zakon.rada.gov.ua/laws/show/558-IX\#Text (accessed 23 November 2021).

2. Setting the Distance! Law and Business: website. Available at: https://zib.com.ua/ua/142090-distanciyne_ kriminalne_provadzhennya_v_umovah_p-oshirennya_ko.html (accessed 23 November 2021).

3. Boyko S. (2020) Kryminalna praktyka «pid sousom» pandemii [Crimean practice «under the sauce» of pandemics]. Yurydychna hazeta [Legal newspaper], no. 22(728). Available at: https://yur-gazeta.com/publications/practi-ce/ kriminalne-pravo-ta-proces/kriminalna-praktika-pid-sousom-pandemiyi.html (accessed 23 November 2021).

4. Criminal Procedure Code of Ukraine: Code of Ukraine from June 13, 2012 № 4651-VI. Available at: https://zakon.rada.gov.ua/laws/show/4651-17\#Text (accessed 07 November 2021).

5. Pasyuk T. V., Tsimbal P. V. (2020) Problemni pytannia zastosuvannia rezhymu videokonferentsii u kryminalnomu protsesi pid chas pandemii [Problems of video conferencing in criminal proceedings during the pandemic]. Juridical scientific electronic journal, no. 8, pp. 408-411.

6. Ovchinnikova O. V. (2018) Perspektivy ispolzovaniya videokonferents-svyazi v elektronnom sudoproizvodstve [Prospects for the use of videoconferencing in electronic court proceedings]. Law and order: history, theory, practice, no. 4(19), pp. 21-25. 
7. Kaplina O. V., Tumanyants A. R., Sharenko S. L. (2020) Sudochynstvo u kryminalnomu provadzhenni pid chas pandemii covid-19: mizhnarodnyi dosvid ta vitchyzniana praktyka [Judiciary in criminal procedure during the COVID-19 pandemic: international experience and domestic practice]. Comparative and Analytical Law, no. 3, pp. 141-167.

8. Commentary to Chapter 26 of the CPC of the Republic of Kazakhstan. Available at: https://online.zakon.kz/ Document/?doc_id=33547929\#pos=5;-108 (accessed 07 November 2021).

9. Knyazev V. V. (2020) Dystantsiine kryminalne provadzhennia: problemni pytannia ta perspektyvy [Remote criminal procedure: problems and prospects]. Priority Strains of Modernization of the System of Law: Materials of the Second Scientific and Practical Conference, Zaporizhzhya, 15-16 january 2020. Kherson: Young Scientist, pp. 126-131.

10. Shingariov D. O. (2016) Okremi pytannia zabezpechennia prav ta zakonnykh interesiv osib pry provedenni dopytu u rezhymi videokonferentsii pid chas dosudovoho rozsliduvannia [Specific protection of rights and legitimate interests of persons during the interview in videoconferencing mode during in-court investigations]. Problems of legality, vol. 135 , pp. 212-224.

11. Criminal Procedure Code of the Republic of Moldova of 14.03.2003 № 122-XV. Available at: http://continent-online.com/ Document/?doc_id=3039-7729\#pos-=6;-143 (accessed 09 November 2021).

12. How do the courts work after the lifting of the state of emergency? Supreme Court of the Republic of Kazakhstan: website. Available at: https://sud.gov.kz/rus/news/kak-rabotayut-sudy-posle-snyatiya-rezhima-chp (accessed 14 November 2021).

13. Kazakhstan citizens may appeal to the court from any gadget. Supreme Court of the Republic of Kazakhstan: website. Available at: https://sud.gov.kz/rus/news/kazah-stancy-mogut-obratitsya-v-sud-s-lyubogo-gadzheta (accessed 14 November 2021).

14. About start of functioning of subsystems (modules) of Unified Court Information and Telecommunication System (UTS): announcement of the Supreme Council of Justice of 04.09.2021. Available at: https://zakon.rada.gov.ua/ rada/show/n0001910-21\#n5 (accessed 18 November 2021).

15. Regulations on the Functioning of Individual Subsystems of the Single Judicial Information and Telecommunication System: Decision of the High Council of Justice of 17.08.2021 № 1845/0/15-21. Available at: https://zakon.rada.gov.ua/rada/show/v1845910-21\#n22 (accessed 18 November 2021). 